\title{
Mineral fibre analysis and routes of exposure to asbestos in the development of mesothelioma in an English region
}

\begin{abstract}
Denise Howel, Allen Gibbs, Lorna Arblaster, Layinka Swinburne, Martin Schweiger, Edward Renvoize, Paul Hatton, Frederick Pooley
\end{abstract}

act

-To compare the concentrations of inorganic fibres in the lungs in cases of mesothelioma and controls: to determine whether concentrations of retained asbestos fibres differ with the different exposures identified from interview; and to investigate the existence of a cut off point in concentrations of asbestos Case-control study; 147 confirmed cases of mesothelioma and 122 controls identified from deaths occurring in four districts of Yorkshire between 1979 and 1991. Surviving relatives were interviewed to determine lifetime exposure history to asbestos. Mineral fibre analysis was carried out on lung tissue from postmortem examinations. Results-Odds on high concentrations of retained asbestos fibres were greater in cases than controls. After excluding subjects with occupational and paraoccupational exposure, the odds on high concentrations were still greater in cases than controls, but only significantly so for amphiboles. There was only a weak relation between probability of occupational exposure to asbestos and concentrations of retained asbestos fibres, and no significant difference in fibre concentrations was found between subjects who had been exposed to asbestos through different routes: these comparisons were only based on small groups. There was considerable overlap in concentrations of retained asbestos fibres between cases and controls with and without histories of occupational exposure Conclusions-The study has confirmed previous results of higher concentrations of asbestos fibres in cases than controls, and has shown that this is still found in subjects with little evidence of occupational and para-occupational exposure. The overlap in concentrations of retained asbestos for different groups of subjects did not suggest a clear cut off value. (Occup Environ Med 1999;56:51-58)

Keywords: mesothelioma; asbestos; fibre retention

Recent studies have attempted to measure a dose-response relation between exposure to asbestos and the development of mesothelioma through lung mineral fibre analyses within case-control studies. ${ }^{1-5}$ This study is unique in bringing together detailed exposure histories from interviews and mineral fibre analyses in a relatively large number of cases and controls from the same communities. It arose from local concern about the incidence of mesothelioma in parts of Yorkshire. Many cases were linked to three factories that used large amounts of asbestos, and there has been speculation that some cases were associated with merely living near one of them. ${ }^{6}$ However, many other local industries used asbestos and we decided to investigate all potential industrial sources of exposure to asbestos. The association between mesothelioma and exposure to asbestos through different routes based on interview information has been reported previously. ${ }^{7}$

The objectives in this part of the study were (a) to compare the concentrations and type of retained inorganic lung fibres in cases of mesothelioma and controls, (b) to determine whether concentrations of retained asbestos fibres in the lung vary with the different exposures identified by interview information, and (c) to investigate whether there is a natural cut off in concentrations of retained asbestos fibres in the lungs which separates most cases of mesothelioma from controls, and indicates likely occupational exposure.

\section{Subjects and methods} STUDY SUBJECTS AND EXPOSURE HISTORIES Cases of malignant mesothelioma occurring in four Yorkshire districts during the period January 1979 to December 1991 were identified from several sources, and included in the study if confirmed as definite mesothelioma by two pathologists. Necropsy records were used to identify controls who had died from diseases other than mesothelioma in the same period. Surviving relatives of both cases and controls were interviewed to ascertain lifetime exposure to asbestos through different routes - that is, occupational, paraoccupational (domestic exposure while handling items brought home by a household member), incidental (through hobbies or visits), and residential (living near a particular source of asbestos - such as a factory). However, any exposure to asbestos in the last 15 years of life (by whatever route) was not included.

Exposure through occupational and paraoccupational routes was coded as likely, possible, or unlikely according to the occupation with the highest probability of exposure. Residential 
exposure was coded as likely if the subject lived within $0.5 \mathrm{~km}$ of one or more of the 278 potential industrial sources of asbestos in the area, and unlikely otherwise. The subjects were classified into five groups by their dominant reported route of exposure, occupational, paraoccupational, incidental, residential, and none. The dominant route is deemed to be occupational if such exposure is likely or possible; paraoccupational if such exposure is likely or possible and there is no evidence of occupational exposure, etc. Details of identification of cases and controls, and coding of exposure information are given in a previous paper. ${ }^{7}$

MINERAL FIBRE ANALYSIS

Histological sections obtained from the postmortem specimens of both cases and controls allowed blocks of non-tumourous lung tissue to be identified. The blocks were labelled with a code number, which did not identify it as a case or control, and were forwarded to the Histopathology Department of Llandough Hospital. Electron microscopic mineral fibre analysis was carried out blind to case status. Because the lung tissue was embedded in paraffin wax, the blocks were dewaxed with xylene and the tissues dried to a constant weight. Tissue samples were digested in $40 \%$ potassium hydroxide, washed, and then ashed at $350^{\circ} \mathrm{C}$ for 3 hours in an atmosphere of oxygen. It has been found that the combination gives the cleanest background for counting and typing fibres, and gives good preservation without causing breakages. ${ }^{8}$ The final abstract was suspended in distilled water and aliquots of known volume were filtered on to nucleopore filters. These were carbon coated, the filters were dissolved in chloroform, and the carbon films mounted on to gold electron microscope support grids for transmission electron microscopy. All fibres $>0.5 \mu \mathrm{m}$ were counted and typed by a standard routine energy dispersive $x$ ray analysis technique. ${ }^{9}$ A fibre was defined as a particle with a 3:1 axial ratio and parallel sides. 100 to 200 fibres were examined for each analysis.

Mineral fibres analyses are expressed as millions of fibre/g (f/g) dry weight of lung tissue. The lowest detectable fibre concentration is 0.1 million $\mathrm{f} / \mathrm{g}$ : any samples with less than this are denoted by $<0.1$ million $\mathrm{f} / \mathrm{g}$ in the results. This paper concentrates on some of the identified fibre types or combinations of these; amosite, crocidolite, chrysotile, total amphibole fibres (the majority of which are amosite and crocidolite), and total non-asbestos fibres. Total asbestos fibre concentrations were used for one analysis in this paper. Given the known variation in measurements when lung tissue samples are processed in different laboratories, absolute fibre concentrations are perhaps less useful than relative figures. Hence, concentrations of retained fibre have been coded as high or low for a particular fibre type, when high is defined as being in the top third of values found in all subjects for that fibre type. For instance, high concentrations of non-asbestos fibres are classed as $>28.6$ million $\mathrm{f} / \mathrm{g}$, whereas for chrysotile the range is $>3.1$ million $\mathrm{f} / \mathrm{g}$.
STATISTICAL ANALYSIS

Many of the statistical analyses compared cases with controls while taking demographic variables into account. To facilitate this, sets of cases and controls were matched for sex, age at death (to within 10 years), and year of death (to within 2 years): the sets ranged in size from one case matched with one control, to seven cases matched to eight controls. The choice of matched sets rather than matched pairs made best use of the scarce remaining subjects as others were excluded from subsequent analyses.

Conditional logistic regression was used to compare the occurrence of high concentrations of retained fibres in cases and controls ${ }^{10}$ : the model incorporated terms to further adjust for age, year of death, and district, as the matching criteria were quite wide. The effect on patterns of concentrations of retained fibre by exposure to asbestos through different routes was investigated by successively excluding subjects who had been exposed by occupational and paraoccupational routes. The same matched sets were used for all analyses with the exclusions as described: if all cases in a set were excluded, the controls in that set were not used. A nonparametric test for trend was used to compare fibre concentrations within groups with different routs of occupational exposure. ${ }^{11}$ KruskalWallis tests were used to compare typical concentrations of fibres between groups with different exposure routes.

\section{Results}

In the study area and period 316 cases were identified: pathological confirmation of malignant mesothelioma was possible in 226. Exposure histories were available for 185 cases and 159 controls: these were the subjects of a previous paper. ${ }^{7}$ Of these, 147 cases and 122 controls had both exposure histories from interviews and lung mineral fibre analyses: they were split into 45 matched sets.

\section{COMPARING CONCENTRATIONS OF LUNG FIBRES} IN CASES AND CONTROLS

Table 1 gives the frequencies of retained fibres for all cases and controls, including typical and extreme values. The median concentrations of all asbestos fibre types were higher in cases than controls, but not for non-asbestos fibres. Concentrations of any asbestos fibre type $>5$ million $\mathrm{f} / \mathrm{g}$ were uncommon in controls, whereas for cases, concentrations $>50$ million $\mathrm{f} / \mathrm{g}$ were unusual for amosite, crocidolite, and chrysotile fibres but more common for nonasbestos fibre types.

Table 2 compares the odds of high concentrations of retained fibres between cases and controls. The odds ratio linking high concentrations of specific fibre types and mesothelioma are given first by considering each fibre type separately, and then adjusted for concentrations of the other fibre types. The first section of the table gives the results for all subjects. It shows that the odds on high concentrations of retained fibres were significantly greater for cases than controls, for all fibre types. When adjustment is made for other fibre concentrations, the odds were still greater for 
Table 1 Distribution of retained fibres in the lung tissue of cases $(n=147)$ and controls $(n=122)$ by fibre type

\begin{tabular}{|c|c|c|c|c|c|c|c|c|c|c|}
\hline & \multicolumn{2}{|c|}{ Non-asbestos } & \multicolumn{2}{|c|}{ Chrysotile } & \multicolumn{2}{|c|}{ Amosite } & \multicolumn{2}{|c|}{ Crocidolite } & \multicolumn{2}{|c|}{ Total amphiboles } \\
\hline & $\begin{array}{l}\text { Cases } \\
(\%)\end{array}$ & $\begin{array}{l}\text { Controls } \\
(\%)\end{array}$ & $\begin{array}{l}\text { Cases } \\
(\%)\end{array}$ & $\begin{array}{l}\text { Controls } \\
(\%)\end{array}$ & $\begin{array}{l}\text { Cases } \\
(\%)\end{array}$ & $\begin{array}{l}\text { Controls } \\
(\%)\end{array}$ & $\begin{array}{l}\text { Cases } \\
(\%)\end{array}$ & $\begin{array}{l}\text { Controls } \\
(\%)\end{array}$ & $\begin{array}{l}\text { Cases } \\
(\%)\end{array}$ & $\begin{array}{l}\text { Controls } \\
(\%)\end{array}$ \\
\hline \multicolumn{11}{|c|}{ Million fibres/g: } \\
\hline$<0.1$ & 4 & 21 & 19 & 41 & 36 & 70 & 23 & 73 & 8 & 56 \\
\hline $0.1-0.9$ & 1 & 3 & 9 & 20 & 20 & 15 & 14 & 19 & 12 & 22 \\
\hline $1-4.9$ & 9 & 16 & 44 & 29 & 16 & 10 & 20 & 7 & 26 & 16 \\
\hline $5-9.9$ & 18 & 16 & 14 & 7 & 10 & 2 & 12 & 0 & 14 & 2 \\
\hline $10-49.9$ & 42 & 33 & 13 & 2 & 9 & 3 & 14 & 1 & 19 & 4 \\
\hline$\geqslant 50$ & 26 & 11 & 1 & 1 & 8 & 0 & 17 & 0 & 22 & 0 \\
\hline Minimum & $<0.1$ & $<0.1$ & $<0.1$ & $<0.1$ & $<0.1$ & $<0.1$ & $<0.1$ & $<0.1$ & $<0.1$ & $<0.1$ \\
\hline Median & 22.2 & 7.8 & 2.4 & 0.4 & 0.7 & $<0.1$ & 2.6 & $<0.1$ & 5.7 & $<0.1$ \\
\hline Maximum & 498 & 660 & 89.1 & 240 & 687 & 29.1 & 15390 & 14.2 & 16096 & 30.7 \\
\hline
\end{tabular}

cases but there was no longer a significant relation with non-asbestos and chrysotile fibres: however, it should be noted that all the odds ratio estimates have wide $95 \%$ confidence intervals (95\% CIs).

Interview information is used to explore whether the relation still holds when subjects first with occupational exposure and then those with paraoccupational exposure to asbestos, are excluded. Subsequent sections of table 2 show the results of successively excluding cases and controls: firstly those with likely or possible occupational exposure, and then those with paraoccupational exposure. Four extra cases and one control have been excluded from these and subsequent analyses because it was not clear that any occupational exposure had occurred at least 15 years before death (the assumed minimum latency). These results showed similar patterns: the numbers of subjects with high concentrations decreased, but there were still high odds ratios for crocidolite and total amphiboles, and to a lesser extent for chrysotile. However, the 95\% CIs around all these estimates of odds ratios widened as the number of subjects available for analysis decreased. When subjects with occupational and likely paraoccupational exposure were excluded, higher concentrations of retained fibres were still more common in cases than controls. Too few subjects remained in the other groups with different exposure routes for further analysis.

ASSOCIATION BETWEEN EXPOSURE HISTORIES AND MINERAL FIBRE ANALYSES

Comparing groups with different routes of occupational exposure

Table 3 gives the median concentrations of retained fibres and sample size for cases and controls within each of the groups with different routes of occupational exposure, and the result of testing the hypothesis that there is a trend in fibre concentrations with the probability that there has been occupational exposure to asbestos. The results show a relation that was not very strong: there was evidence of a significant trend of higher fibre concentrations with increasing probability of occupational exposure to asbestos, for amosite and total amphiboles among the cases, and in amosite among the controls. Relatively high concentrations of crocidolite and chrysotile were found in some subjects who had no identified occupational exposure.

Table 2 Odds ratios (ORs) linking high levels of specific fibre types and mesothelioma

\begin{tabular}{|c|c|c|c|c|c|c|}
\hline & \multicolumn{2}{|c|}{ High levels $(n)$} & \multicolumn{2}{|c|}{ Unadjusted } & \multicolumn{2}{|c|}{ Adjusted } \\
\hline & Cases & Controls & ORt & $95 \% C I$ & $O R \neq$ & $95 \% C I$ \\
\hline \multicolumn{7}{|c|}{ All subjects ( 147 cases, 122 controls): } \\
\hline Non-asbestos & 62 & 27 & 2.5 & (1.4 to 4.3$)$ & 1.4 & $(0.7$ to 2.8$)$ \\
\hline Chrysotile & 68 & 22 & 3.8 & (2.1 to 6.8$)$ & 1.9 & (0.96 to 3.8$)$ \\
\hline Amosite & 71 & 19 & 5.7 & (3.0 to 10.8 ) & 3.0 & (1.4 to 6.5$)$ \\
\hline Crocidolite & 84 & 7 & 20.5 & $(8.4$ to 50$)$ & 13.9 & (5.6 to 34$)$ \\
\hline Amphiboles & 82 & 7 & 16.2 & (7.0 to 37 ) & 12.4 & (5.2 to 29$)$ \\
\hline \multicolumn{7}{|c|}{ Excluding subjects with likely occupational exposure ( 62 cases, 94 controls): } \\
\hline Non-asbestos & 18 & 22 & 1.8 & (0.85 to 3.6$)$ & 0.87 & (0.37 to 2.3$)$ \\
\hline Chrysotile & 30 & 19 & 3.4 & $(1.6$ to 7.0$)$ & 2.1 & (0.91 to 5.0$)$ \\
\hline Amosite & 25 & 23 & 2.8 & (1.2 to 6.5$)$ & 1.6 & $(0.53$ to 5.0$)$ \\
\hline Crocidolite & 33 & 5 & 20 & (5.7 to 68$)$ & 16.3 & ( 4.4 to 60$)$ \\
\hline Amphiboles & 26 & 6 & 9.2 & (3.2 to 27 ) & 7.1 & (2.3 to 22$)$ \\
\hline \multicolumn{7}{|c|}{ Excluding subjects with likely or possible occupational exposure ( 26 cases, 48 controls): } \\
\hline Non-asbestos & 12 & 13 & 2.5 & $(0.75$ to 8.1$)$ & 0.9 & (0.18 to 4.7$)$ \\
\hline Chrysotile & 14 & 11 & 4.8 & (1.4 to 15.9$)$ & 2.4 & (0.5 to 11.1 ) \\
\hline Amosite & 6 & 5 & 3.2 & (0.75 to 13.6$)$ & 0.63 & (0.05 to 7.4$)$ \\
\hline Crocidolite & 16 & 2 & 25.1 & (3.2 to 208 ) & 25.9 & (1.9 to 352$)$ \\
\hline Amphiboles & 13 & 1 & 24.7 & (2.6 to 236$)$ & 17.4 & (1.6 to 193$)$ \\
\hline \multicolumn{7}{|c|}{ Excluding subjects with likely occupational or likely para-occupational exposure (47 cases, 83 controls): } \\
\hline Non-asbestos & 18 & 22 & 1.4 & $(0.65$ to 3.1$)$ & 0.8 & $(0.30$ to 2.1$)$ \\
\hline Chrysotile & 23 & 17 & 3.5 & $(1.5$ to 8.1$)$ & 2.3 & $(0.88$ to 6.1$)$ \\
\hline Amosite & 14 & 13 & 2.5 & $(1.0$ to 6.1$)$ & 1.4 & $(0.43$ to 4.2$)$ \\
\hline Crocidolite & 22 & 4 & 15.4 & $(4.3$ to 56$)$ & 16.4 & (3.6 to 75$)$ \\
\hline Amphiboles & 17 & 5 & 9.3 & (2.7 to 32 ) & 6.8 & (1.9 to 25$)$ \\
\hline
\end{tabular}

$\star$ The ranges labelled high are the top third of values in this study for that fibre type and are $\geqslant 28.6$ units for non-asbestos fibres, $\geqslant 3.1$ for chrysotile, $\geqslant 0.8$ for amosite, $\geqslant 1.6$ for crocidolite, and $\geqslant 4.9$ for total amphiboles. Units are million fibres $/ g$.

†Adjusting for age, year of death, district.

$\ddagger$ Adjusting for age, year of death, district, and other fibre concentrations. 
Table 3 Summary statistics for concentrations of retained fibre by case or control and occupational exposure group

\begin{tabular}{|c|c|c|c|c|c|c|c|c|}
\hline & \multicolumn{4}{|l|}{ Cases } & \multicolumn{4}{|l|}{ Controls } \\
\hline & $\begin{array}{l}\text { Likely } \\
(n=80)\end{array}$ & $\begin{array}{l}\text { Possible } \\
(n=36)\end{array}$ & $\begin{array}{l}\text { Unlikely } \\
(n=27)\end{array}$ & $p$ Value & $\begin{array}{l}\text { Likely } \\
(n=17)\end{array}$ & $\begin{array}{c}\text { Possible } \\
(n=43)\end{array}$ & $\begin{array}{l}\text { Unlikely } \\
(n=61)\end{array}$ & $p$ Value \\
\hline \multicolumn{9}{|c|}{ Non- asbestos: } \\
\hline Min & $<0.1$ & 1.4 & 3.8 & 0.98 & $<0.1$ & $<0.1$ & $<0.1$ & 0.82 \\
\hline LQ & 6.2 & 8.9 & 7.8 & & $<0.1$ & 2.1 & 2.2 & \\
\hline Median & 22.4 & 18.2 & 22.1 & & 10.8 & 5.5 & 9.2 & \\
\hline UQ & 66.4 & 40.4 & 71.4 & & 19.1 & 25.4 & 27.8 & \\
\hline $\operatorname{Max}$ & 498 & 210 & 153 & & 660 & 571 & 241 & \\
\hline \multicolumn{9}{|l|}{ Chrysotile: } \\
\hline Min & $<0.1$ & $<0.1$ & $<0.1$ & 0.78 & $<0.1$ & $<0.1$ & $<0.1$ & 0.20 \\
\hline LQ & 0.4 & 0.9 & 1.1 & & $<0.1$ & $<0.1$ & $<0.1$ & \\
\hline Median & 2.5 & 2.1 & 3.4 & & $<0.1$ & 0.2 & 0.5 & \\
\hline UQ & 7.4 & 4.1 & 5.4 & & 1.1 & 1.4 & 2.6 & \\
\hline $\operatorname{Max}$ & 50.3 & 15.6 & 89.1 & & 7.8 & 240 & 19.8 & \\
\hline \multicolumn{9}{|l|}{ Amosite: } \\
\hline Min & $<0.1$ & $<0.1$ & $<0.1$ & $<0.01$ & $<0.1$ & $<0.1$ & $<0.1$ & 0.03 \\
\hline LQ & 0.1 & $<0.1$ & $<0.1$ & & $<0.1$ & $<0.1$ & $<0.1$ & \\
\hline Median & 1.6 & $<0.1$ & 0.2 & & $<0.1$ & $<0.1$ & $<0.1$ & \\
\hline UQ & 17.4 & 0.9 & 0.7 & & 1.4 & 0.3 & $<0.1$ & \\
\hline Max & 687 & 14 & 8.6 & & 11.7 & 29.1 & 27.2 & \\
\hline \multicolumn{9}{|c|}{ Crocidolite: } \\
\hline Min & $<0.1$ & $<0.1$ & $<0.1$ & 0.12 & $<0.1$ & $<0.1$ & $<0.1$ & 0.53 \\
\hline LQ & 0.4 & 0.2 & 0.3 & & $<0.1$ & $<0.1$ & $<0.1$ & \\
\hline Median & 5.4 & 1.3 & 2.0 & & $<0.1$ & $<0.1$ & $<0.1$ & \\
\hline UQ & 57.6 & 5.7 & 17.0 & & 0.7 & 0.2 & 0.1 & \\
\hline Max & 15930 & 82.8 & 228 & & 2.3 & 14.2 & 2.3 & \\
\hline \multicolumn{9}{|c|}{ Total amphiboles: } \\
\hline Min & $<0.1$ & $<0.1$ & $<0.1$ & $<0.01$ & $<0.1$ & $<0.1$ & $<0.1$ & 0.07 \\
\hline LQ & 2.7 & 0.9 & 0.8 & & $<0.1$ & $<0.1$ & $<0.1$ & \\
\hline Median & 13.8 & 2.5 & 4.8 & & 0.7 & $<0.1$ & $<0.1$ & \\
\hline UQ & 157 & 8.2 & 17.8 & & 2.3 & 1.0 & 0.5 & \\
\hline $\operatorname{Max}$ & 16096 & 83.7 & 231 & & 11.7 & 30.7 & 30.2 & \\
\hline
\end{tabular}

Each occupational exposure category includes subjects who may have experienced exposure through other routes. $\mathrm{p}$ Values refer to the test for trend across the three levels of occupational exposure.

$\mathrm{Min}=$ minimum; $\mathrm{LQ}=$ lower quartile; $\mathrm{Med}=$ median; $\mathrm{UQ}=$ upper quartile; Max=maximum.

Comparing exposure routes

Table 4 shows summary statistics of the concentrations of retained fibres by case and control group, and by the likely dominant route of exposure. Subjects judged to have a dominant exposure through incidental or residential routes have been placed in a combined category, because there were so few subjects. Even so, there were very few subjects in some subgroups and therefore it is not possible to make statements with confidence about the patterns of fibre concentrations within them. Overall, no obvious difference existed in typical fibre concentrations between the assumed routes of exposure within the cases and controls. Formal significance tests indicate that we cannot reject the null hypothesis that typical fibre concentrations are similar for subjects with different routes of exposure. However, the very small numbers in some of the groups mean that there is low power to detect anything other than large differences in typical fibre concentrations. It is worth noting that there were some high concentrations of asbestos fibres (particularly chrysotile) in subjects who apparently were only exposed through incidental exposure or living near an industrial source.

Discrepancies between exposure histories and lung mineral fibre analyses

In most cases and controls there was some association between the evidence for past

Table 4 Comparison of concentrations of retained lung fibre levels in cases and controls by assumed routes of exposure

\begin{tabular}{|c|c|c|c|c|c|c|c|c|c|c|}
\hline & \multicolumn{5}{|l|}{ Cases } & \multicolumn{5}{|l|}{ Controls } \\
\hline & $\begin{array}{l}\text { Occup } \\
(n=116)\end{array}$ & $\begin{array}{l}\text { Paraocc } \\
(n=13)\end{array}$ & $\begin{array}{l}\text { Inc Res } \\
(n=7)\end{array}$ & $\begin{array}{l}\text { None } \\
(n=7)\end{array}$ & p Value & $\begin{array}{l}\text { Occup } \\
(n=60)\end{array}$ & $\begin{array}{l}\text { Paraocc } \\
(n=11)\end{array}$ & $\begin{array}{l}\text { Inc Res } \\
(n=20)\end{array}$ & $\begin{array}{l}\text { None } \\
(n=30)\end{array}$ & $p$ Value \\
\hline \multicolumn{11}{|l|}{ Non-asbestos: } \\
\hline Min & $<0.1$ & 5.9 & 5.5 & 3.8 & 0.36 & $<0.1$ & $<0.1$ & $<0.1$ & $<0.1$ & 0.61 \\
\hline Median & 22.2 & 30.4 & 22.1 & 10.6 & & 6.8 & 9.5 & 18.6 & 6.6 & \\
\hline Max & 498 & 87.6 & 153 & 41.3 & & 660 & 24.0 & 241 & 105 & \\
\hline \multicolumn{11}{|l|}{ Chrysotile: } \\
\hline Min & $<0.1$ & $<0.1$ & 0.9 & $<0.1$ & 0.45 & $<0.1$ & $<0.1$ & $<0.1$ & $<0.1$ & 0.58 \\
\hline Median & 2.4 & 1.7 & 5.4 & 3.4 & & 0.2 & 0.6 & 0.3 & 0.9 & \\
\hline Max & 50.3 & 40.9 & 89.1 & 7.3 & & 240 & 6.0 & 19.8 & 10.0 & \\
\hline \multicolumn{11}{|l|}{ Amosite: } \\
\hline Min & $<0.1$ & $<0.1$ & $<0.1$ & $<0.1$ & 0.07 & $<0.1$ & $<0.1$ & $<0.1$ & $<0.1$ & 0.54 \\
\hline Median & 0.9 & $<0.1$ & 0.3 & $<0.1$ & & $<0.1$ & $<0.1$ & $<0.1$ & $<0.1$ & \\
\hline Max & 687 & 2.5 & 1.7 & 8.6 & & 29.1 & 0.5 & 1.6 & 27.2 & \\
\hline \multicolumn{11}{|l|}{ Crocidolite } \\
\hline Min & $<0.1$ & $<0.1$ & $<0.1$ & $<0.1$ & 0.48 & $<0.1$ & $<0.1$ & $<0.1$ & $<0.1$ & 0.91 \\
\hline Median & 2.8 & 5.1 & 0.4 & 1.9 & & $<0.1$ & $<0.1$ & $<0.1$ & $<0.1$ & \\
\hline Max & 15930 & 228 & 32.6 & 97.0 & & 14.2 & 0.5 & 1.6 & 2.3 & \\
\hline \multicolumn{11}{|l|}{ Amphiboles: } \\
\hline Min & $<0.1$ & $<0.1$ & $<0.1$ & $<0.1$ & 0.20 & $<0.1$ & $<0.1$ & $<0.1$ & $<0.1$ & 0.55 \\
\hline Median & 7.4 & 5.6 & 1.1 & 4.9 & & $<0.1$ & $<0.1$ & $<0.1$ & $<0.1$ & \\
\hline Max & 16096 & 231 & 32.6 & 105.6 & & 30.7 & 1.0 & 3.2 & 30.2 & \\
\hline
\end{tabular}

Occup=occupational; Paraocc=paraoccupational; Inc Res=incidental ( 2 cases and 7 controls) or residential ( 5 cases and 13 controls). 
Table 5 Examples of subjects with discrepant asbestos exposure from mineral fibre analysis and interviews

\begin{tabular}{|c|c|c|c|c|c|c|c|c|c|c|}
\hline \multirow[b]{2}{*}{ Code No } & \multirow[b]{2}{*}{$\operatorname{Sex}$} & \multirow[b]{2}{*}{$\begin{array}{l}\text { Year of } \\
\text { death }\end{array}$} & \multirow[b]{2}{*}{$\begin{array}{l}\text { Age at } \\
\text { death }\end{array}$} & \multicolumn{4}{|l|}{ Exposure history } & \multicolumn{3}{|c|}{ Fibre concentration, $\left(10^{6} \mathrm{f} / \mathrm{g}\right)$} \\
\hline & & & & Occupational & $\begin{array}{l}\text { Paraocc } \\
\text { upation al }\end{array}$ & Incidental & Residential & Amosite & Crocidolite & Chrysotile \\
\hline \multicolumn{11}{|c|}{ Cases with low concentrations of asbestos retained by the lung, but reported occupational exposure: } \\
\hline 79 & M & 1983 & 54 & $\begin{array}{l}\text { Fitter who built ovens } \\
\text { (asbestos mentioned) } \\
1953-77\end{array}$ & None & None & $\begin{array}{l}\text { Lived near Bell's } \\
\text { Asbestos (1967-85) }\end{array}$ & $<0.1$ & $<0.1$ & $<0.1$ \\
\hline 124 & M & 1987 & 68 & $\begin{array}{l}\text { Joiner including at power } \\
\text { station (asbestos } \\
\text { mentioned) }\end{array}$ & None & None & Insufficient to code & 0.80 & $<0.1$ & $<0.1$ \\
\hline 233 & M & 1989 & 59 & $\begin{array}{l}\text { Joinery and maintenance } \\
\text { (asbestos mentioned) } \\
1943-48 \text { and 1950-89 }\end{array}$ & None & Did DIY & Unlikely & 0.36 & $<0.1$ & $<0.1$ \\
\hline \multicolumn{11}{|c|}{ Controls with no apparent asbestos exposure and high concentrations of asbestos fibre retained by the lung: } \\
\hline 323 & $\mathrm{~F}$ & 1989 & 54 & $\begin{array}{l}\text { Clerk (at wiremakers, } \\
\text { tailors, and civil service) } \\
\text { 1931-76 }\end{array}$ & None & None & Unlikely & 2.0 & $<0.1$ & 1.3 \\
\hline 349 & $\mathrm{~F}$ & 1984 & 69 & $\begin{array}{l}\text { Clerk (at pram shop, } \\
\text { builders, and furniture } \\
\text { shop) 1931-76 }\end{array}$ & None & None & Unlikely & $<0.1$ & $<0.1$ & 7.0 \\
\hline 400 & M & 1988 & 59 & $\begin{array}{l}\text { Hairdresser 1942-49, made } \\
\text { chocolates 1949-55, carpet } \\
\text { salesman 1955-82 }\end{array}$ & None & None & Unlikely & $<0.1$ & 1.4 & 4.4 \\
\hline
\end{tabular}

exposure to asbestos obtained from interview and the results of the mineral fibre analysis: those people whose life history suggested that exposure to asbestos had higher retained concentrations of lung fibres and vice versa. It is difficult to state exactly what would constitute disagreement between the evidence of exposure through the two methods, but table 5 gives examples in which discrepancies occurred. The second control (code no 349) also had 1 million $\mathrm{f} / \mathrm{g}$ of tremolite, but otherwise, no other amphiboles were detected.
Existence of a cut off level of lung fibre concentration for occupational exposure to asbestos This section concentrates on comparison between two groups of subjects whose life history suggests diametrically opposite exposure experience from interview and lung fibre analysis - that is, the 80 cases with likely occupational exposure to asbestos and the 61 controls with no known exposure. Figure 1 A-D compares the cumulative frequency distributions in these cases and controls, for each of four fibre groups. Figure $1 \mathrm{~A}$ shows that
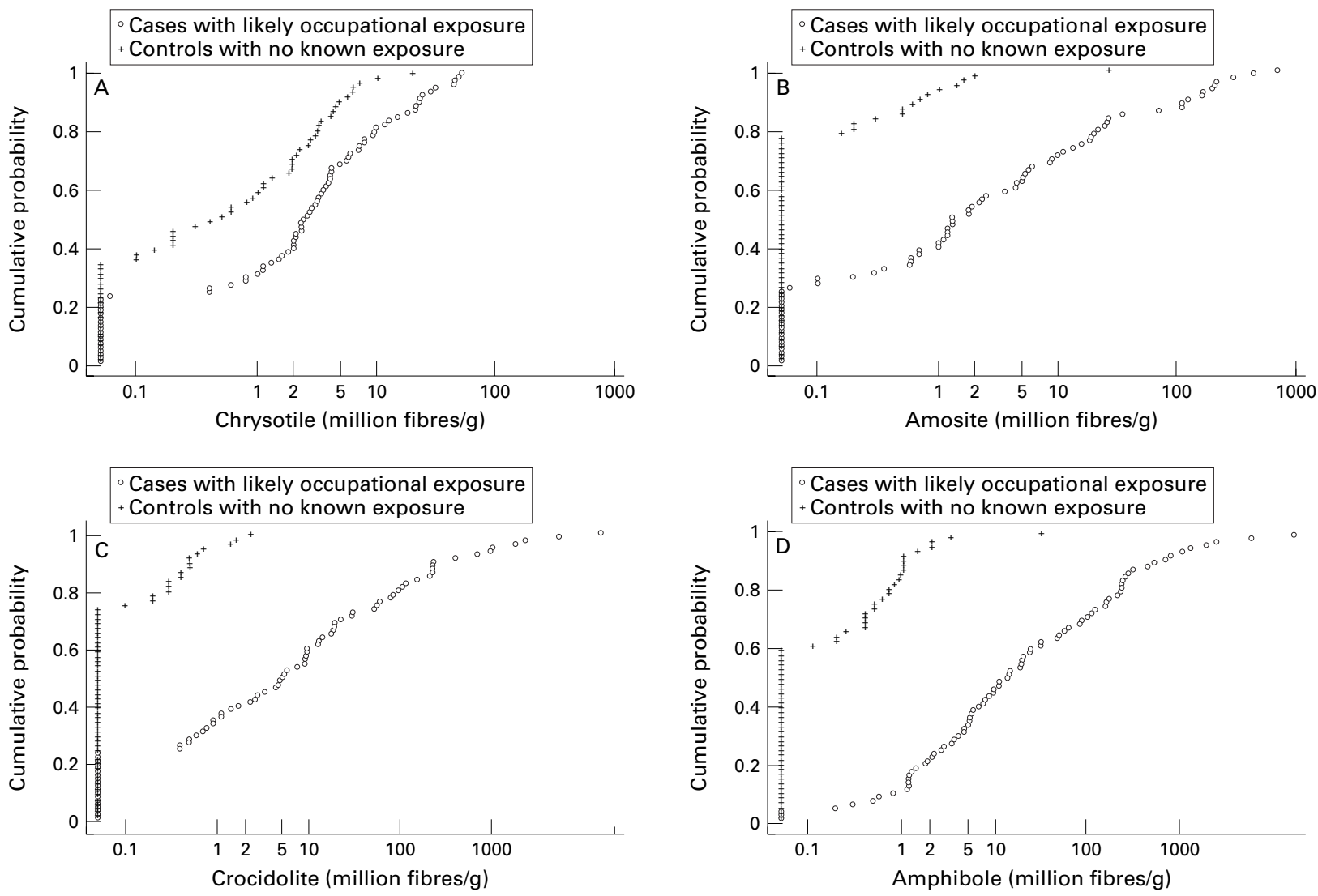

Figure 1 Cumulative distribution of (A) chrysotile, (B) amosite, (C) crocidolite, (D) amphiboles. 


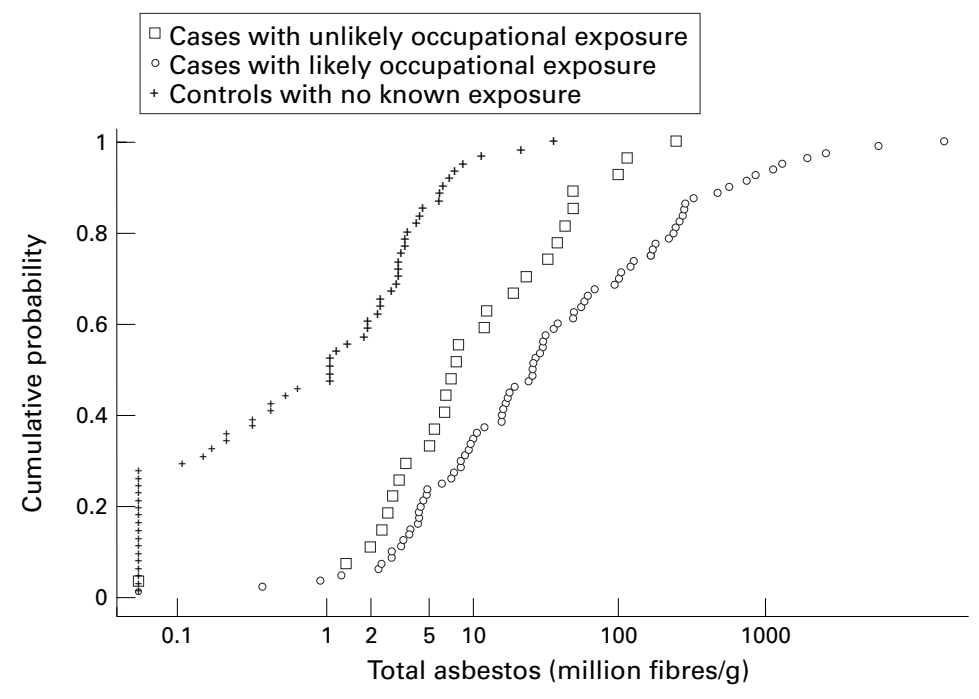

Figure 2 Cumulative distribution of total asbestos.

$22 \%$ of the occupationally exposed cases had no trace of chrysotile, compared with $34 \%$ of the apparently unexposed controls. When chrysotile fibres were detectable, they varied between 0.1 and 50 million $\mathrm{f} / \mathrm{g}$ in the cases, and up to 20 million $\mathrm{f} / \mathrm{g}$ in the controls. There was a tendency for chrysotile concentrations to be a little higher in cases than controls, but the two distributions were not very different. By contrast, figure $1 \mathrm{D}$ shows that only $4 \%$ of cases with likely occupational exposure had no detectable concentrations of total amphibole fibres, as opposed to $60 \%$ of the unexposed controls. These two cumulative distributions are widely separated.

There was a wide range of fibre concentrations seen among the cases. Most of the controls with no known exposure to asbestos had undetectable concentrations of amphibole fibres, but there were some controls with concentrations up to 30 million $\mathrm{f} / \mathrm{g}$. The overlap in fibre concentrations found in occupationally exposed cases and non-exposed controls was less for the amphiboles than for chrysotile or non-asbestos fibres. Nevertheless, there was a wide range of fibre concentrations in both cases and controls, which suggests that there are no obvious thresholds to indicate occupational exposure in this series of subjects.

Figure 2 shows the cumulative distribution of all asbestos fibres, as this grouping is often used in other publications. This figure also shows a third group of subjects, the 27 cases with unlikely occupational exposure to asbestos. The cumulative distribution of total asbestos concentrations in cases with unlikely occupational exposure lies between that of cases with likely occupational exposure and controls without any known exposure. However, there is considerable overlap in concentrations of retained asbestos in the two groups of cases which makes it difficult to distinguish occupational exposure from fibre concentrations alone.

\section{Discussion}

Eighty to ninety per cent of cases of mesothelioma in the United Kingdom are thought to be related to exposure to asbestos ${ }^{12}$ : although some mesotheliomas occur without a history of exposure, and in some cases the concentration of retained fibre is not above background values. ${ }^{13}{ }^{14}$ Other putative causes include exposure to the non-asbestos mineral fibre erionite, ${ }^{15}$ radiation, ${ }^{16}$ and the $S V-40$ virus. ${ }^{17}$

Exposure assessments in this study were obtained on a large number of cases and controls, from the same community, through both lung mineral fibre analyses and exposure histories. This is unusual; other case-control studies have had deficiencies of control groups from a different population to cases $^{2}$, lacked exposure histories, ${ }^{42}$ or had a small sample size. $^{135}$ This study showed that the odds of high concentrations of retained fibres were significantly greater in cases than controls for all types of fibre considered; when adjustment was made for other fibre types, the odds were still significantly higher in cases for amphiboles. The results from other laboratories cannot be directly compared numerically with these results, because of differences in the methods of identifying fibres and choice of subjects, but the existing case-control studies that used mineral fibre analysis show similar patterns of high concentrations of asbestos fibres in cases compared with controls. ${ }^{218}$ Ideally, the methods of fibre analysis should be standardised, but this has not occurred so far.

Given the established differences in retained asbestos fibres between cases and controls, and the known role of occupational exposure to asbestos, we were interested in the relative concentrations of fibres in cases and controls when occupational exposure had not occurred. We have been able to establish that the concentrations of retained asbestos fibres were still greater in cases than controls when subjects with occupational exposure were excluded, but we are unable to provide much information on the fibre concentrations of those exposed only through incidental or residential routes. Despite more comprehensive exposure histories than other case-control studies, we have not been able to provide firm evidence on the risks of residential exposure or the concentrations of fibres in the lungs of those so exposed, because of the few subjects who were not also occupationally or paraoccupationally exposed to asbestos. ${ }^{7}$ Some studies have linked mesothelioma with residential exposure to crocidolite near mines ${ }^{19}$ and factories ${ }^{20}{ }^{21}$; but most others have not established such a link. These studies used exposure histories from interviews or records rather than lung fibre analyses to classify residential exposure to asbestos. However, as the criteria for residential exposure in these studies were very variable, or other routes of exposure had not always been properly taken into account, there is still no strong consensus on the link between residential exposure and mesothelioma.

We were able to investigate the association between the concentrations of retained fibres and histories of exposure to asbestos. The first comparison was between concentrations of retained fibres in cases and controls divided into groups by the probability of occupational exposure to asbestos. The results showed a 
fairly weak relation: there was only evidence of a significant trend of higher concentrations of fibres with increasing probability of occupational exposure for amosite and total amphiboles among the cases, and in amosite among the controls. Relatively high concentrations of crocidolite and chrysotile were found in some subjects who had no identified occupational exposure; this may be because some occupational exposure to asbestos has been missed, or because these subjects were exposed to high concentrations of these fibres through other routes-for example, paraoccupational exposure. Given the considerable variation in exposure concentrations between the different jobs which involve asbestos, it would be expected that there would also be a large variation in concentrations of retained fibres within the likely and possible occupational exposure groups. This was found, and was more pronounced in the cases than the controls.

Previous case series examining the relation between estimates of exposure by occupational hygienists and concentrations of mineral fibres in the lungs in workers within particular occupational groupings-for example, mining, shipyard, and asbestos factory workers-have shown positive associations. ${ }^{22-25}$ Studies have also shown higher amphibole concentrations in the lung tissues of exposed workers with disease related to asbestos than in exposed workers without such disease. ${ }^{22} 2627$ However, the associations are much weaker in those case series with multiple occupations, ${ }^{28}{ }^{29}$ because of the difficulties in estimating past exposure in different locations, where work practices were very different. The exposure histories in our study indicate that subjects had multiple occupations and there did not seem to be any clear differences in typical fibre concentrations between the different assumed dominant routes of exposure among cases and controls. However, it is difficult to make precise statements about the patterns of fibre concentrations because there were few subjects in some of the exposure route subgroups. Many of the paraoccupational cases showed similar fibre concentrations to occupational cases, which agrees with a previous study of paraoccupational mesotheliomas. ${ }^{30}$

In most of our cases and controls there was a positive association between the evidence obtained from interviews for past exposure to asbestos and the analysis of mineral fibres in the lungs; where the life history suggested exposure to asbestos there were higher concentrations of retained mineral fibres and vice versa. However, there were some discrepancies. Some subjects with positive occupational histories had low concentrations of retained asbestos; similarly, some subjects with no apparent exposure to asbestos from the interview data had high concentrations of retained asbestos. Unexpectedly high concentrations of asbestos fibres may have occurred because the interviewee did not know about, or recall, exposure to asbestos. Unexpectedly low fibre concentrations may be because concentrations of retained fibres are complicated by the deposition and clearance mechanisms: these depend on fibre type and dimension, and may result in little evidence of exposure. However, the fibre dimensions to which people were exposed through varying routes in the past is not known, and information on fibre type is extremely limited.

Retained concentrations of fibres in the lungs have been used to clarify uncertainty about occupational exposure to asbestos. Although the absolute concentrations of asbestos detected in a lung sample vary between laboratories, some papers state that concentrations of total asbestos fibres $>1$ million $\mathrm{f} / \mathrm{g}$ dry weight indicate an occupational exposure to asbestos. ${ }^{13242831}$ Other papers suggest that different cut off concentrations or fibre types should be used for this purpose ${ }^{8}{ }^{32}$ : depending on the type of analysis (TEM or SEM) and the methodology of the laboratory. Considering all fibre types, although their job history indicated that these cases had been exposed to asbestos at work, it is possible that this was only at low concentrations. However, in this study, although cases with likely occupational exposure from their job history had generally higher concentrations of total asbestos fibres than those cases without a history of occupational exposure, who in turn had higher concentrations than controls with a similar history, there was considerable overlap between the concentrations of retained fibres in the three groups. There is no obvious cut off concentration in total asbestos fibres which would reliably indicate that occupational exposure to asbestos had taken place. It would be possible to choose a concentration which those without occupational exposure rarely exceeded, but many subjects with occupational exposure would also fall below this. This finding also applies to the other fibre types considered.

There are difficulties in assessing past exposure in case-control studies because the biologically important exposures occurred several decades before onset of the disease. Not all subjects in this study had lung blocks available; there were hardly any contemporary measurements of concentrations of airborne fibre; there were only retrospective descriptions of exposure to asbestos from interviews with relatives or other contacts, which were unobtainable in some subjects. These descriptions have limitations; personal recollections, especially about another person, can be incomplete or unreliable. This is illustrated in table 5 where there are occasional gaps in the occupational or residential histories, or difficulties in deciding on exposure categories-for example, how likely is occupational exposure if working as a clerk for a builder? Job descriptions are often used as a proxy for exposure to asbestos. However, this method may be more accurate for certain industries than others. The mixture of occupations experienced in a lifetime in this study make this task difficult. Possible intermittent exposures are also difficult to categorise.

Mineral fibre analysis also has its limitations. Deposition of fibres within the lung is dependent on the size of the fibres and the amount of fibres within the breathing zone of the person. Compared with amphiboles, chrysotile is 
generally not retained within the lungs, and therefore mineral fibre analysis does not adequately reflect lifetime exposure to chrysotile. ${ }^{32}$ It has also been recommended that mineral fibre analyses should be performed on pooled samples of several pieces of tissue obtained from the same lung because of variation in the number of fibres obtained from adjacent small samples. ${ }^{83}$ This was not possible in this study because of its retrospective nature; the analyses had to be carried out on the samples of lung tissue available. However, there is no reason to think that systematic bias occurred in either cases or controls.

This study has added to the literature on the part played by different types of asbestos. In industry, the most commonly used type of asbestos was chrysotile (about 93\%): amphiboles were used less often. Asbestos fibre type has been shown to be linked to the risks of mesothelioma: there are numerous studies which indicate that, in the United Kingdom and elsewhere, exposure to amphibole asbestos accounts for nearly all mesotheliomas. ${ }^{22}{ }^{34-36} \mathrm{Chrysotile}$ exposure on its own seems to cause mesothelioma rarely. ${ }^{23}$ Even in the few mesothelioma cases that have occurred in Canadian chrysotile miners and millers, exposure to tremolite, another form of amphibole asbestos which contaminates the chrysotile ore, was thought to be responsible. ${ }^{37} 38$

This study has brought together detailed histories of exposure to asbestos and lung fibre analyses on a group of cases of mesothelioma and controls from the same population. It has provided useful information on the relative risks of concentrations of retained fibres and has further explored this for non-occupational exposure. However, due to the high proportion of subjects with likely or possible occupational exposure, it has not been possible to contribute much to the knowledge of concentrations of retained fibres in cases and controls who have experienced other routes of exposure: a larger study is needed for this. The comparison of our results on fibre burden with those of others is, as always, problematical: standardised mineral fibre analysis techniques across laboratories and standardised postmortem sampling techniques should be agreed on.

We are particularly grateful to the contacts of the cases of mesothelioma and those who acted as controls for their help and othelioma and those who acted as controls for their help and interest. We also acknowledge support given by staff at loca pathology laboratories and medical records departments, staff at of Leeds Medical Library, Leeds City Library, and Bradford City Library. This work was funded by the Colt Foundation.

1 Mowe G, Gylseth B, Hartveit F, et al. Fiber concentration in lung tissue of patients with malignant mesothelioma: case-control study. Cancer 1985;56:1089-93.

2 Rogers AJ, Leigh J, Berry G, et al. Relationship between lung asbestos fiber type and concentration and relative risk of mesothelioma. A case-control study. Cancer 1991;67:191220 .

3 Tuomi T, Huuskonen MS, Virtamo M, et al. Relative risk of Tuomi T, Huuskonen MS, Virtamo M, et al. Relative risk of
mesothelioma associated with different levels of exposure mesothelioma associated with different levels of exposur

to asbestos. Scand $\mathcal{F}$ Work Environ Health 1991;17:404-8.
4 McDonald JC, Armstrong B, Case B, et al. Mesothelioma McDonald JC, Armstrong B, Case B, et al. Mesothelioma
and asbestos fiber type. Evidence from lung tissue analyses. and asbestos fiber type. E

5 Gaudichet A, Janson X, Monchaux G. Assessment by analytical microscopy of the total lung fibre burden in mesothelioma patients matched with four other pathological series. Ann Occup Hyg 1988;32(supp 1):213-23.

6 Arblaster L, Hatton P, Howel D, et al. Occupational and environmental links to mesothelioma deaths occuring in Leeds during 1971-87. F Public Health Med 1995;17:297304 $7 \begin{array}{r}\text { Howel D, Arblaster L, Swinburne L, et al. Routes of asbes- } \\ \text { tos exposure and the development of mesothelioma in an }\end{array}$ tos exposure and the development of mesotheliom

8 Gibbs AR, Pooley FD. Analysis and interpretation of inorganic mineral particles in lung tissues. Thorax 1996;51: 327-34.

9 Pooley FD, Clarke NJ. Quantitative assessment of inorganic fibrous particles in dust samples with an analytic electron microscope. Ann Occup Hyg 1979;22:253-71.

10 Collett D. Modelling binary data. London: Chapman and Hall, 1991.

11 Cuzick J. A Wilcoxon-type test for trend. Stat Med 1985;4:87-90.

12 Gibbs AR. Role of asbestos and other fibres in the development of diffuse malignant mesothelioma. Thorax 1990;45: 649-54.

13 Gibbs AR, Jones JSP, Pooley FD, et al. Non-occupational malignant mesotheliomas. In: Bignon J, Peto J, Saracci R, eds. Non-occupational exposures to mineral fibres. Lyon: IARC, 1989:219-28.

14 Srebro SH, Roggli VL, Samsa GP. Malignant mesothelioma associated with low pulmonary tissue asbestos burdens: a light and scanning electron microscopic analysis of 18 cases. Mod Pathol 1995;8:614-21.

15 Baris YI, Simonato L, Artvinli M, et al. Epidemiological and environmental evidence of the health effects of exposure to erionite fibres: a four year study in the Cappadocian region of Turkey. Int $\mathcal{F}$ Cancer 1987;39:10-17.

16 Peterson JT, Greenberg SD, Buffler PA. Non-asbestos related malignant mesothelioma. Cancer 1984;54:951-60.

17 Pepper C, Jasani B, Navabi H, et al. Simian virus 40 large T antigen (SV40LTAg) primer specific DMNA amplification in human pleural mesothelioma tissue. Thorax 1996;51: 1074-6.

18 McDonald JC, McDonald AD. The epidemiology of mesothelioma in historical context. Eur Respir $\mathcal{F}$ 1996;9: $1932-42$.

19 Wagner JC, Sleggs CA, Marchand P. Diffuse pleural mesothelioma and asbestos exposure in the North Western Cape Province. Br f Ind Med 1960;17:260-71.

20 Newhouse ML, Thompson H. Mesothelioma of the pleura and peritoneum following exposure to asbestos in the London area. Br f Ind Med 1965;22:261-9.

1 Hain E, Dalquen $\mathrm{P}$, Bohlig $\mathrm{H}$, et al. Catamnestic investigations of the origins of mesothelioma. Internationales Archiv fur Arbeitsmedizin 1974;33:15-37.

22 Wagner JC, Newhouse ML, Corrin B, et al. Correlation between fibre content of the lung and disease in east London asbestos factory workers. Br f Ind Med 1988;45:305-8.

23 Acheson ED, Gardner MJ, Pippard EC, et al. Mortality of two groups of women who manufactured gas masks from chrysotile and crocidolite asbestos. Br F Ind Med 1982;39: 344-8.

24 Takahashi K, Case BW, Dufresne A, et al. Relation between lung asbestos fibre burden and exposure indices based on job history. Oсcup Environ Med 1994;51:461-9.

25 Sebastien P, McDonald JC, McDonald AD, et al. Respiratory cancer in chrysotile textile and mining industries: exposure inferences from lung analysis. Br f Ind Med 1989; 46:180-7.

26 Wagner JC, Moncrieff CB, Coles R, et al. Correlation between fibre content of the lungs and disease in naval dockyard workers. Br f Ind Med 1986;43:391-5.

27 Albin M, Johansson L, Pooley FD, et al. Mineral fibres, fibrosis, and asbestos bodies in lung tissue from deceased asbestos cement workers. Br f Ind Med 1990;47:767-74.

28 Tuomi T, Huuskonen MS, Tammileto L, et al. Occupational exposure to asbestos as evaluated from work histories and analysis of lung tissues from patients with mesothelioma. Brf Ind Med 1991;48:48-52.

29 Tossavainen A, Karjalainen A, Karhunen PJ. Retention of asbestos fibres in the human body. Environ Health Perpect 1994;102(suppl 5):253-5.

30 Gibbs AR, Griffiths DM, Pooley FD, et al. Comparison of fibre types and size distributions in lung tissues of paraoccupational and occupational cases of malignant mesothelioma. Br F Ind Med 1990;47:621-6.

31 Case BW. Biological indicators of chrysotile exposure. Ann Occup Hyg 1994;38:503-18.

32 Churg A. Analysis of lung asbestos content. Br f Ind Med 1991;48:649-52.

33 Churg A, Wood P. Observations on the distribution of asbestos fibres in human lungs. Environ Res 1983;31:37480 .

34 Jones JSP, Pooley FD, Sawle GW, et al. The consequences of exposure to asbestos dust in a war time gas mask factory. In: JC Wagner, ed. Biological effects of mineral fibres. Lyon: IARC Scientific Publications, 1980:637-53.

35 Wagner JC, Pooley FD, Berry G, et al. A pathological and mineralogical study of asbestos-related deaths in the mineralogical study of asbestos-related deaths in the 31 .

36 McDonald AD, McDonald JC, Pooley FD. Mineral fibre content of lung in mesothelial tumours in North America. Ann Occup Hyg 1982;26:417-22.

37 Churg A, Wiggs B, DePaoli L, et al. Lung asbestos content in chrysotile workers with mesothelioma. Am Rev Respir Dis 1984;130:1042-5.

38 Dufresne A, Begin R, Churg A, et al. Mineral fibre content of lungs in patients with mesothelioma seeking compensation in Quebec. Am $\mathcal{F}$ Respir Crit Care Med 1996;153:711- 